【論文】

\title{
伝達関数法による面内曲げ有限変位問題の解析*
}

\section{A TRANSFER FUNCTION METHOD FOR FINITE DISPLACEMENTS OF TWO-DIMENSIONAL BEAMS}

\author{
阿井正 博**. 村上淳*** \\ By Masahiro AI and Atsushi MURAKAMI
}

\section{1.はじめに}

1 次元構造要素の系の解析手法である伝達マトリック ス法は,ループ数の少ない構造を比較的小さいマトリッ クスで扱える利点がよく知られており, 最も複雑な薄肉 曲線はりでの展開 ${ }^{4}$, , ) も示され, 微小変位問題では基本 的にすでに確立された手法といえる.

一般に幾何学的非線形問題の解析は線形化有限変位理 論としての展開が最初であり多くの座屈問題が説明され てきたが，伝達マトリックス法においても，Möl110) の I 形断面直線はりに対する非線形伝達マトリックス展 開, Unger ${ }^{12)}$ によるはりの横倒れ座屈の解析, 遠田 ${ }^{5}$ の 薄肉曲線 はりの伝達マトリックスによる非線形解析, Yoshida-Imoto ${ }^{14)}$ のはりの弹塑性横倒れ座屈の解析, 山森・吉田 ${ }^{13)}$ の 1 ループ・ラーメンの面外座屈解析, な どのはりの立体挙動に対する線形化有限変位理論程度の 展開が報告されており, 平面アーチの一般的面内座屈を 扱う同程度の伝達マトリックス展開 ${ }^{11)}$ 示されている.

一方近年では，より高次の非線形性を含む連続系基礎 方程式が次々に報告されており, より大きい有限変位そ のものを扱う離散化変位法の展開も示され, 有限変位の 後の不安定現象が解析される段階にある.微小变位問題 で最初確立された変位法が, その後, 以上のような有限 変位問題に対する非線形代数系に拡大展開されてきたよ うに，伝達マトリックス法においてもその初期值問題と しての展開といら基本概念は有限变位問題に対して同様 に拡大して考えることができる.

本報告は，変位の大きさを制限しない 1 次元構造要素 の有限変位問題において, 線形系での伝達マトリックス

* 本論文の一部内容は, 土木学会第 36 回年次学術講演会に て発表 ${ }^{2}$.

** 正会員 工博 法政大学助教授 工学部土木工学科

*** 正会員 工修 石川島播磨重工業（株）
法に準じた初期値問題としての解法を考えるものであ り，具体的には有限変位有限ひずみ問題としての面内は りの基礎方程式 ${ }^{1)}$ を微小ひずみの範囲で初期值問題に展 開し数值計算を行っている. このとき, その伝達関係 が，マトリックス形式でなく, 連立非線形代数式の形と なることより仮に伝達関数法と称した.

\section{1 次元構造要素の初期值展開}

\section{(1) Taylor 展開}

任意階連立常微分方程式が新しい変数の導入により 1 階連立常微分方程式に变換されることはよく知られてお り, 長手方向 Lagrange 座標 $\zeta$ を独立変数とした 1 次 元構造要素の 1 階微分形での基礎方程式を

$$
\frac{d \boldsymbol{s}}{d \zeta}=\boldsymbol{F}(\zeta ; \boldsymbol{s}, \overline{\boldsymbol{p}}), 0 \leqq \zeta \leqq l
$$

と表わす.ここに， $\boldsymbol{s}(\zeta)$ はいわゆる状態ベクトルとよ ばれる断面の幾何学的および力学的状態を規定する未知 量の組, $\overline{\boldsymbol{p}}(\zeta)$ は作用する分布外力を表わす既知関数の 組であり, l は要素の無応力時の長さを表わす.このと き,式（1）に掠いて $\zeta=0$ での状態量が

$$
\left.\boldsymbol{s}\right|_{\zeta=0}=\boldsymbol{s}_{0}
$$

で与えられる初期値問題の系を考える.

状態量 $s$ の 1 階微分は式（1）で直接与えられるが, その $n$ 階微分が $s$ と $\overline{\boldsymbol{p}}$ の微係数に関して

$$
\frac{d^{n} \boldsymbol{s}}{d \zeta^{n}}=\boldsymbol{F}^{[n]}\left(\zeta ; \boldsymbol{s}, \overline{\boldsymbol{p}}, \overline{\boldsymbol{p}}^{\prime}, \cdots, \overline{\boldsymbol{p}}^{(n-1)}\right)
$$

の形 $\left(\boldsymbol{F}^{[1]}=\boldsymbol{F}\right)$ で表わされるとき, $n+1$ 階微分は,

$$
\begin{aligned}
\frac{d^{n+1} \boldsymbol{s}}{d \zeta^{n+1}}= & \frac{\partial \boldsymbol{F}[n]}{d \zeta}+\left[\frac{\partial \boldsymbol{F}^{[n]}}{\partial \boldsymbol{s}}\right] \frac{d \boldsymbol{s}}{d \boldsymbol{\zeta}} \\
& +\sum_{m=1}^{n}\left[\frac{\partial \boldsymbol{F}^{[n]}}{\partial \overline{\boldsymbol{p}}^{(m-1)}}\right] \frac{d \overline{\boldsymbol{p}}^{(m-1)}}{d \zeta}
\end{aligned}
$$

と展開されることと式 (1) の代入を考えれば 


$$
\begin{aligned}
\frac{d^{n+1} \boldsymbol{s}}{d \zeta^{n+1}}= & \boldsymbol{F}^{[n+1]}\left(\zeta ; \boldsymbol{s}, \overline{\boldsymbol{p}}, \overline{\boldsymbol{p}}^{\prime}, \cdots, \overline{\boldsymbol{p}}^{(n)}\right) \\
& \ldots \ldots \ldots \ldots \ldots \ldots \ldots \ldots \ldots \ldots \ldots \ldots \ldots \ldots \ldots \ldots \ldots \ldots \\
\boldsymbol{F}^{[n+1]}= & \frac{\partial \boldsymbol{F}[n]}{\partial \zeta}+\left[\frac{\partial \boldsymbol{F}[n]}{\partial \boldsymbol{s}}\right] \boldsymbol{F} \\
& +\sum_{m=1}^{n}\left[\frac{\partial \boldsymbol{F}^{[n]}}{\partial \overline{\boldsymbol{p}}^{(m-1)}}\right] \overline{\boldsymbol{p}}^{(m)} \ldots \ldots \ldots \ldots \ldots
\end{aligned}
$$

と表わすことができ, ある点 $\zeta$ での状態量の任意階微 係数 $d^{n} s / d \zeta^{n}$ をその点での状態量 $\boldsymbol{s}$ と外力 $\overline{\boldsymbol{p}}(\zeta)$ の 微係数に関して展開することができることが帰納法的に いえる.ただし，以上での記号 ()$\left.^{\prime} （\right)^{(n)}$ は 5 に関 する 1 階, $n$ 階微分を意味する.

$\zeta=0$ での状態量 $\boldsymbol{s}_{0}$ が式 (2) で与えられる初期値問 題では，それを各 $\boldsymbol{F}^{[n]}, n=1,2, \cdots$, に代入すれば同点 での状態量の各階微係数を知ることができ， $N$ 次まで の Taylor 展開を考えて状態量の分布を

$$
\begin{aligned}
\boldsymbol{s}(\zeta ; & \left.\boldsymbol{s}_{0}, \boldsymbol{p}\right)=\boldsymbol{s}_{0}+\sum_{n=1}^{N} \frac{\zeta^{n}}{n !} \\
& \times \boldsymbol{F}^{[n]}\left(0 ; \boldsymbol{s}_{0}, \bar{p}(0), \cdots \overline{\boldsymbol{p}}(0)^{(n-1)}\right)+0\left(\zeta^{N+1}\right)
\end{aligned}
$$

の形で近似的に得ることができる.また， $\boldsymbol{s}_{0}($ ( $\boldsymbol{p}(\zeta))$ に対する以上の $\boldsymbol{s}(\zeta)$ のつり合い状態で, 初期值の微小 変化 $\delta \boldsymbol{s}_{0}$ を考えたときの 対応する状態量分布の 微小変 化は，式（5）を $s_{0}$ に関してそのまま微分して

$$
\begin{aligned}
\delta & s\left(\zeta ; \boldsymbol{s}_{0}, \overline{\boldsymbol{p}}\right)=\left[[I]+\sum_{n=1}^{N} \frac{\zeta^{n}}{n !}\right. \\
\times & {\left[\frac { \partial } { \partial \boldsymbol { s } _ { 0 } } \boldsymbol { F } [ n ] \left(0 ; \boldsymbol{s}_{0}, \overline{\boldsymbol{p}}(0), \overline{\boldsymbol{p}}^{\prime}(0), \cdots,\right.\right.} \\
& \left.\left.\left.\overline{\boldsymbol{p}}(0)^{(n-1)}\right)\right]+\left[\mathbf{0}\left(\zeta^{N+1}\right)\right]\right] \delta \boldsymbol{s}_{0} \cdots \cdots \cdots
\end{aligned}
$$

と展開することができる。

式 (5),(6) は，式 (1)，(2) の設定に対する一般的な 展開結果を示したものであるが，その関数関係を，あら ためて

$$
\begin{aligned}
& \boldsymbol{s}(\zeta)=\boldsymbol{E}\left(\zeta ; \boldsymbol{s}_{0}, \overline{\boldsymbol{p}}\right) \\
& \delta \boldsymbol{s}(\zeta)=\left[U\left(\zeta ; \boldsymbol{s}_{0}, \overline{\boldsymbol{p}}\right)\right] \delta \boldsymbol{s}_{0}
\end{aligned}
$$

と表わすものとする.

線形系での伝達マトリックスの級数展開に関する一般 的な説明（たとえば，文献 6)）と同じ意味での有限変 位問題での非線形伝達関係の一般展開は以上のように説 明される. 数ある級数展開法の中で Taylor 展開法の数 学理論は十分整備されており, 微分方程式一般において 収束域が問題となる場合が少なくないとされているが, その理論の単純さは工学での適用にきわめて有効と考え られ，全体区間を適当に分割し，各分割区間での展開を 連続させれば収束性を大幅に改善することができる. Taylor 展開の基点 $\zeta_{i}$ が正則点であればその近傍で式 （5）は明らかに収束傾向にあり，全区間を適当な部分区 間 $\Delta l_{i}\left(\zeta_{i+1}=\zeta_{i}+\Delta l_{i}\right)$ に分割して, $\Delta l_{i}$ の幅ごとでの展
開を境界点で連続させれば，すなわち数值積分法として の 1 区間展開として用いるものとすれば，区間 $[0, l] に$ 特異点を含まない限り収束を得ることができる，一定の 精度に対して展開幅 $\Delta l_{i}$ と Taylor 展開の次数は相補的 関係にあると考えてよいが，1階常微分方程式の系では 最低 1 次の展開，すなわち折線近似の展開であっても $\Delta l_{i}$ を無限小とする 極限では収束值を得ることができ る.また，前述のような分割を考えれば分割点で，集中 外力, 折れ曲がり等の初等微分式では扱えない条件を, 断面の幾何学的・力学的連続性を別に考えて処理するこ とができ，任意の形状・外力条件のはりを扱うことがで きる。

\section{（2）境界値問題への適用}

他の固体連続体と同様に 1 次元構造要素の系の変形の 問題は一般に境界值問題であるが，(1) での初期值問題 としての展開は，他端境界条件に関する繰返し計算を考 えることにより境界值問題にも適用することができる. ここでは簡単のために，1ループの問題，すなわち $\zeta=$ $0, l$ の両端面に関する 2 点境界值問題を考える.

変位場の導入された 1 次元要素の断面の空間位置は有 限 $\Gamma$ 個のパラメーターで規定されるが，その各方向の 運動に対して断面応力がする仕事を考えれば断面の力学 量も同数自由度で表わされるといえる. 状態量 $\boldsymbol{s}$ はそ の両方を規定するパラメーターの組であるが，その幾何 学量と力学量は前述の意味でこれまで必ずしも対応して 定められているとはいえず，幾何学量 $\boldsymbol{x}=\left\{x_{1}, \cdots, x_{\Gamma}\right\}$ に対する力学量 $\boldsymbol{f}=\left\{f_{1}, \cdots, f_{\Gamma}\right\}$ を, $\boldsymbol{x}$ からの断面微小 変位 $\delta \boldsymbol{x}$ において内積 $\delta W=\boldsymbol{f} \cdot \delta \boldsymbol{x}$ が断面応力のその微 小変位での 実微小仕事を表わすように, 断面応力の $\boldsymbol{x}$ 方向成分として定義するものとし ${ }^{1)}, x$ と $\boldsymbol{f}$ で定まる 状態量をあらためて $\boldsymbol{t}=\{\boldsymbol{x}, \boldsymbol{f}\}$ と表わす. このとき, $\boldsymbol{s}$ と $\boldsymbol{t}$ が異なる場合でも，断面状態を規定する意味では 同等であり，互いに可逆の関係にある. 式 $(5)^{\prime},(6)^{\prime}$ の 各分割区間での展開を 全体区間に連続して $\boldsymbol{t}$ の状態量 に変換した同等の関係を

$$
\begin{aligned}
& \boldsymbol{t}_{l}=\boldsymbol{E}^{*}\left(l ; \boldsymbol{t}_{0}, \overline{\boldsymbol{p}}, \overline{\boldsymbol{P}}_{i}\right) \ldots \ldots . . \\
& \delta \boldsymbol{t}_{l}=\left[U^{*}\left(l ; \boldsymbol{t}_{0}, \overline{\boldsymbol{p}}, \overline{\boldsymbol{P}}_{\boldsymbol{i}}\right)\right] \delta \boldsymbol{t}_{0}
\end{aligned}
$$

と表わす.ここに， $\overline{\boldsymbol{P}}_{\boldsymbol{i}}$ は要素境界点での集中外力を表 わすパラメーターの組である.

前述のように定めた $\boldsymbol{x}$ と $\boldsymbol{f}$ では，境界条件を受ける 断面で，それらの中の対応する 2 つのパラメーターは同 時に境界条件を受けることはなく，しかし，必ずいずれ か一方は境界条件で規定される．境界条件で規定される 自由度を $t^{B}$, 規定されない自由度を $t^{V}$ と表わしその 境界值を $\overline{\boldsymbol{t}}^{B}$ と表わす. 繰返し計算において $\boldsymbol{t}_{0}{ }^{B}$ は $\overline{\boldsymbol{t}}^{B}{ }^{B}$ に固定するものとすれば，考えている 境界値問題は， 
$\boldsymbol{t}_{l}{ }^{B}\left(\boldsymbol{t}_{0}{ }^{V}\right)=\overline{\boldsymbol{t}}_{l}{ }^{B}$ となる $\boldsymbol{t}_{0}{ }^{V}$ を求める問題に帰着するが, 式 (8) の接線伝達マトリックスより $\boldsymbol{t}_{l}{ }^{B}, t_{0}{ }^{V}$ に対応す る行, 列成分を取り出して得られる接線関係

$$
\delta \boldsymbol{t}_{l}{ }^{B}=\left[u^{*}\left(l ; \boldsymbol{t}_{0}{ }^{V}, \overline{\boldsymbol{p}}, \overline{\boldsymbol{P}}_{i}\right)\right] \delta \boldsymbol{t}_{0}{ }^{V}
$$

を用いれば，いわゆる Newton-Raphson 法系の繰返し 計算で $\boldsymbol{t}_{l}{ }^{B}=\overline{\boldsymbol{t}}_{l}{ }^{B}$ となる $\boldsymbol{t}_{0}{ }^{V}$ の収束值を得ることが考え られる.

\section{3. 面内はり問題への適用}

\section{(1) 伝達関係と接線係数}

一様断面はりの変形の問題を Euler-Bernoulli の仮定 のもとに考えると，ひずみは長手方向直ひずみのみが生 じるが，その直ひずみを長手方向物体固定座標に関する 伸び率で表現し, 弾性定数を介して有限な伸び率に対し ても直応力のみが線形関係で生じるとしたときの基礎方 程式 ${ }^{11}$ は,

ひずみ一変位関係：

$$
\left.\begin{array}{l}
\epsilon_{G}=\sqrt{\left(x_{G}\right)^{2}+\left(y_{G}{ }^{\prime}\right)^{2}}-1 \\
\kappa=\frac{-y_{G^{\prime} x_{G}{ }^{\prime \prime}+x_{G}{ }^{\prime} y_{G}{ }^{\prime \prime}}}{\left(x_{G}\right)^{2}+\left(y_{G}\right)^{2}}
\end{array}\right\}
$$

つり合い方程式 :

$$
\begin{aligned}
& \frac{d}{d \zeta}\left(\frac{1}{g_{G}}\left[\begin{array}{cc}
x_{G^{\prime}}, & -y_{G^{\prime}} \\
y_{G^{\prime}}, & x_{G^{\prime}}
\end{array}\right]\left\{\begin{array}{c}
N \\
\frac{M^{\prime}-\bar{m}}{g_{G}}
\end{array}\right\}\right) \\
& +\left\{\bar{p}_{x}\right\}=\left\{\begin{array}{l}
0 \\
0
\end{array}\right\}
\end{aligned}
$$

構成方程式 :

$$
N=E A \epsilon_{G}, M=-E I\left(\kappa-\kappa^{0}\right) \cdots \cdots \cdots \cdots(12 \cdot \mathrm{a}, \mathrm{b})
$$

力学的境界条件式 :

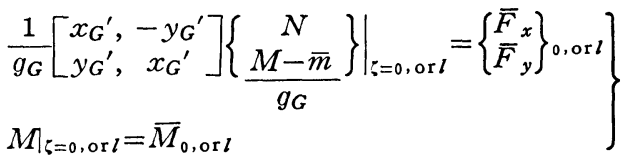

$$
\begin{aligned}
& \cdot(13 \cdot a, b)
\end{aligned}
$$

幾何学的境界条件式：

$$
\left.\begin{array}{l}
\left.\left\{x_{G}, y_{G}\right\}\right|_{\zeta=0, \text { or } l}=\left\{\bar{x}_{G}, \bar{y}_{G}\right\}_{0, \mathrm{or} l} l \\
\left.\arctan \left(y_{G}{ }^{\prime} / x_{G}{ }^{\prime}\right)\right|_{\zeta=0, \text { or } l}=\bar{\theta}_{0, \mathrm{or} l}
\end{array}\right\} \cdots(14 \cdot \mathrm{a}, \mathrm{b})
$$

と表わされる. ただし， $\zeta$ は無応力時の重心線の長さに 沿う物体固定座標であり”(記号 ( ) 分), 含まれる 既知量は, $E$ : 弾性定数, $A, I$ : 断面積, 重心点まわりの断面 2次モーメント, $l:$ 重心線の無応 力時長さ, $\kappa^{0}(\zeta)$ : 初期曲率, $\left\{\bar{p}_{x}(\zeta), \bar{p}_{y}(\zeta)\right\}, \bar{m}(\zeta)$ : $\zeta$ 座標関する分布外力, 分布外力モーメント, $\left\{\bar{F}_{x}\right.$, $\left.\bar{F}_{y}\right\}, \bar{M}: \zeta=0$, or $l$ の端面に作用する力, モーメント， $\left\{\bar{x}_{G}, \bar{y}_{G}\right\}, \bar{\theta}: \zeta=0$, or $l$ での拘束位置, 回転, の諸量で あり, 未知量は, $\left\{x_{G}(\zeta), y_{G}(\zeta)\right\}:$ 重心線のつり合い 形状, $\epsilon_{G}(\zeta), \kappa(\zeta):$ つ合い状態での重心線の伸び率,

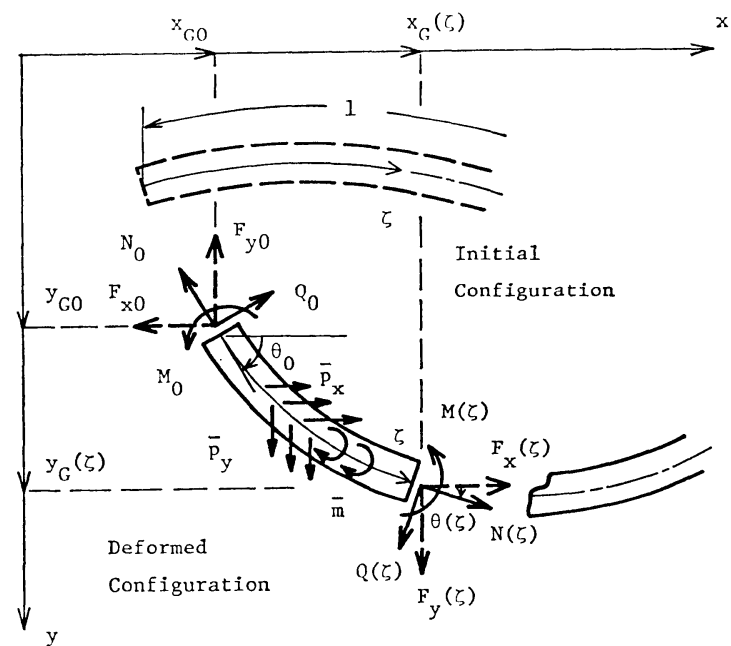

Fig. 1 Two-Dimensional Beam Element.

$\zeta$ 座標に関する曲線, $N(\zeta), M(\zeta)$ : 断面軸力, 曲げモ ーメント， $\left(g_{G}=\sqrt{\left.\left(x_{G}\right)^{2}+\left(y_{G}\right)^{2}\right)}\right.$ である (Fig. 1).

以上の連立常微分方程式の系は,たわみ角 $\theta(\zeta)(\tan \theta$ $=y_{G^{\prime}}\left(x_{G^{\prime}}\right)$ とせん断力

$$
Q(\zeta)=\left(M^{\prime}-\bar{m}\right) / g_{G}
$$

を新しい未知関数として導入して, 式 $(12 \cdot a, b)$ のも とに $\kappa(\zeta), \epsilon_{G}(\zeta)$ を消去すれば, 次の 1 階常微分方程式 に書き換えることができる. 式 $(10 \cdot a),(12 \cdot a)$ より得ら れる $x_{G}{ }^{\prime}=g_{G} \cos \theta=(1+N / E A) \cos \theta, y_{G}{ }^{\prime}=(1+N / E A)$ $\sin \theta$ の関係は

$$
\frac{d}{d \zeta}\left\{x_{G}, y_{G}\right\}=\left[T_{G}(\theta)\right]^{T}\left\{1+\frac{N}{\alpha}, 0\right\}
$$

$$
\text { ただし, }\left[T_{G}(\theta)\right]=\left[\begin{array}{cr}
\cos \theta, & \sin \theta \\
-\sin \theta, & \cos \theta
\end{array}\right] . .
$$

と表わすことができ， $\kappa=d \theta / d \zeta$ を式 $(12 \cdot \mathrm{b})$ で考えれ ば

$$
\frac{d \theta}{d \zeta}=-\frac{M}{\beta}+\kappa^{0}
$$

が得られる.ここに, $\alpha=E A, \beta=E I$. また, 式 (11)を 式 (13·a) のもとに積分した後, 左辺 ( ) 内の直交、 トリックス $\left[T_{G}\right]^{T}$ を右辺に移して

$$
\{N, Q\}=\left[T_{G}(\theta)\right]\left\{F_{x}, F_{y}\right\}
$$

$$
\text { ただし, }\left\{\begin{array}{l}
F_{x}(\zeta) \\
F_{y}(\zeta)
\end{array}\right\}=\left\{\begin{array}{l}
\bar{F}_{x_{0}} \\
\left.\bar{F}_{y_{0}}\right\}
\end{array}\right\}-\int_{0}^{\zeta}\left\{\bar{p}_{x}\right\} d \zeta
$$

と展開され, さらに $g_{G}=1+N / \alpha$ を式 (15) で考えて

$$
\frac{d M}{d \zeta}=\left(1+\frac{N}{\alpha}\right) Q+\bar{m}
$$

となり, 状態量 $s=\left\{x_{G}, y_{G}, \theta, N, Q, M\right\}$ に関する式 (16・a〜d) の 1 階微分方程式の系が得られる.ここに, 記号 \{\} は列ベクトルを表わす.

式（17）の直交マトリックス $\left[T_{G}\right]$ の $\zeta$ に関する微 
分が式 $(16 \cdot \mathrm{b})$ のもとに

$$
\frac{d}{d \zeta}\left[T_{G}(\theta)\right]=\left[D_{G}(\theta)\right] \frac{M^{*}}{\beta}
$$

ただし，

$$
\left.\begin{array}{l}
{\left[D_{G}(\theta)\right]=\left[\begin{array}{cc}
\sin \theta, & -\cos \theta \\
\cos \theta, & \sin \theta
\end{array}\right]} \\
M^{*}=M-\beta \kappa^{0}
\end{array}\right\}
$$

となることと, マトリックス演算のうえで

$$
\left.\begin{array}{l}
{\left[D_{G}\right]\{A, B\}=\left[T_{G}\right]\{-B, A\}} \\
\left(\left[D_{G}\right]^{T}\{A, B\}=\left[T_{G}\right]^{T}\{B,-A\}\right)
\end{array}\right\}
$$

の関係があることより, 式 $(16 \cdot \mathrm{a}, \mathrm{c})$ 右辺のような形式 の $\zeta$ に関する微分は, 一般に

$$
\frac{d}{d \zeta}\left(\left[T_{G}\right]\left\{\begin{array}{l}
A \\
B
\end{array}\right\}\right)=\left[T_{G}\right]\left(\left\{\begin{array}{l}
A^{\prime} \\
B^{\prime}
\end{array}\right\}+\frac{M^{*}}{\beta}\left\{\begin{array}{c}
-B \\
A
\end{array}\right\}\right)
$$

のように展開される.

$\kappa^{0}(\zeta), \bar{m}(\zeta),\left\{F_{x}(\zeta), F_{y}(\zeta)\right\}$ が既知関数であること
を考えれば, 力学量 $\{N, Q, M\}$ の中の $N, Q$ の 1 階 微分は式 (22) の形で, $M^{\prime}$ は式 $(16 \cdot d)$ でそれぞれ $\boldsymbol{s}$ に関する代数式で表わされるが, それ以上の各階微係数 も, 各微分の中で生じる $N, Q, M$ の 1 階微係数に順次 先に得られている代数表示式を代入することにより， $\mathbf{s}$ に関する代数式として展開することができる. また，幾 何学量 $\left\{x_{G}, y_{G}, \theta\right\}$ に関しても, 式 (16・a) の式 (22) の形式での各階微分演算式と式 $(16 \cdot b)$ の各階微分式中 に先に得られている $N, Q, M$ の代数表示微係数を代入 して, $s$ に関する代数式に展開することができる.

等分布外力 $\left\{\bar{p}_{x}, \bar{p}_{y}\right\}$ : const. のみを受ける曲率一定 ( $\kappa^{0}:$ const.) の円弧はり要素に対する微小ひずみの範囲 での展開を考える. 微小な伸び率は後に付加項として考 虑するものとし1), 重心線の不伸長 $(\alpha=\infty)$ の条件のも とに $\zeta=0$ のまわりでの 6 次までの Taylor 展開の結果 は次のようである.

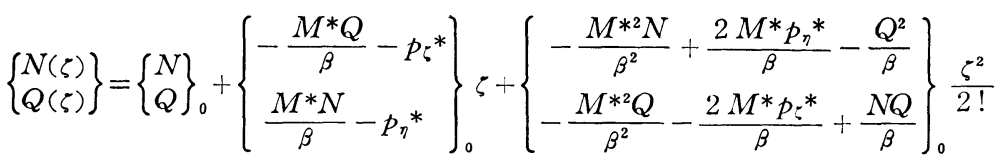

$$
\begin{aligned}
& +\left\{\begin{array}{c}
\frac{M^{* 3} Q}{\beta^{3}}+\frac{3 M^{* 2} p_{\zeta}{ }^{*}}{\beta^{2}}-\frac{4 M^{*} N Q}{\beta^{2}}+\frac{4 Q p_{\eta}{ }^{*}}{\beta}, \\
-\frac{M^{* 3} N}{\beta^{3}}+\frac{3 M^{* 2} p_{\eta}^{*}}{\beta^{2}}+\frac{M^{*} N^{2}}{\beta^{2}}-\frac{3 M^{*} Q^{2}}{\beta^{2}}-\frac{N p_{\eta}{ }^{*}}{\beta}-\frac{3 Q p_{5}^{*}}{\beta}
\end{array}\right\}_{0}^{\frac{\zeta^{3}}{3 !}} \\
& +\left\{\begin{array}{l}
\frac{M^{* 4} N}{\beta^{4}}-\frac{4 M^{* 3} p_{\eta}^{*}}{\beta^{3}}-\frac{4 M^{* 2} N^{2}}{\beta^{3}}+\frac{7 M^{* 2} Q^{2}}{\beta^{3}}+\frac{8 M^{*} N p_{\eta}^{*}}{\beta^{2}}+\frac{14 M^{*} Q p_{5}^{*}}{\beta^{2}} \\
-\frac{4 N Q^{2}}{\beta^{2}}-\frac{4 p_{\eta}^{* 2}}{\beta}, \\
\frac{M^{* 4} Q}{\beta^{4}}+\frac{4 M^{* 3} p_{\zeta}^{*}}{\beta^{3}}-\frac{11 M^{* 2} N Q}{\beta^{3}}-\frac{6 M^{*} N p_{5}^{*}}{\beta^{2}}+\frac{16 M^{*} Q p_{\eta}^{*}}{\beta^{2}}+\frac{N^{2} Q}{\beta^{2}} \\
-\frac{3 Q^{2}}{\beta^{2}}+\frac{4 p_{\zeta}^{*} p_{\eta}^{*}}{\beta},
\end{array}\right\}_{0}^{\frac{\zeta^{4}}{4 !}}
\end{aligned}
$$

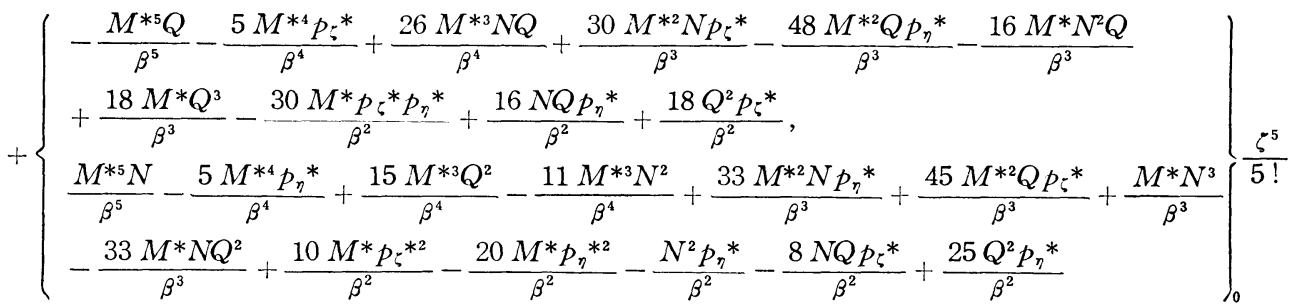

$$
\begin{aligned}
& \left(-\frac{M^{* 6} N}{\beta^{6}}+\frac{6 M^{* 5} p_{\eta}{ }^{*}}{\beta^{5}}+\frac{26 M^{* 4} N^{2}}{\beta^{5}}-\frac{31 M^{* 4} Q^{2}}{\beta^{5}}-\frac{104 M^{* 3} N p_{\eta}{ }^{*}}{\beta^{4}}-\frac{124 M^{* 3} Q p_{5}{ }^{*}}{\beta^{4}}\right. \\
& -\frac{16 M^{* 2} N^{3}}{\beta^{4}}+\frac{164 M^{* 2} N Q^{2}}{\beta^{4}}-\frac{60 M^{* 2} p_{\zeta}{ }^{* 2}}{\beta^{3}}+\frac{78 M^{* 2} p_{\eta}{ }^{* 2}}{\beta^{3}}+\frac{32 M^{*} N^{2} p_{\eta}{ }^{2}}{\beta^{3}} \\
& +\left\{\begin{array}{l}
+\frac{144 M^{*} N Q p_{5}{ }^{*}}{\beta^{3}}-\frac{184 M^{*} Q^{2} p_{\eta}{ }^{*}}{\beta^{3}}-\frac{16 N^{2} Q^{2}}{\beta^{3}}+\frac{18 Q^{4}}{\beta^{3}}-\frac{82 Q p_{5}{ }^{*} p_{\eta}{ }^{*}}{\beta^{2}}-\frac{16 N p_{\eta}{ }^{* 2}}{\beta^{2}}, \\
-\frac{M^{* 6} Q}{\beta^{6}}-\frac{6 M^{* 5} p_{5}{ }^{*}}{\beta^{5}}+\frac{57 M^{* 4} N Q}{\beta^{5}}+\frac{100 M^{* 3} N p_{5}{ }^{*}}{\beta^{4}}-\frac{128 M^{* 3} Q_{\eta}{ }^{*}}{\beta^{4}}-\frac{102 M^{* 2} N^{2} Q}{\beta^{4}}
\end{array}\right. \\
& +\frac{78 M^{* 2} Q^{3}}{\beta^{4}}-\frac{138 M^{* 2} p_{5}^{*} p_{\eta}{ }^{*}}{\beta^{3}}-\frac{12 M^{*} N^{2} p_{5}^{*}}{\beta^{3}}+\frac{156 M^{*} Q^{2} p_{5}{ }^{*}}{\beta^{3}}+\frac{192 M^{*} N Q p_{\eta}{ }^{*}}{\beta^{3}} \\
& +\frac{N^{3} Q}{\beta^{3}}-\frac{33 N Q^{2}}{\beta^{3}}+\frac{10 N p_{5}{ }^{*} p_{\eta}{ }^{*}}{\beta^{2}}+\frac{8 Q p_{5}{ }^{* 2}}{\beta^{2}}-\frac{70 Q p_{\eta}{ }^{* 2}}{\beta^{2}} \\
& \int_{0}^{\frac{\zeta^{6}}{6 !}}
\end{aligned}
$$




$$
\begin{aligned}
& M(\zeta)=M_{0}+Q_{0} \zeta+\left(\frac{M^{*} N}{\beta}-p_{\eta}{ }^{*}\right)_{0} \frac{\zeta^{2}}{2}+\left(-\frac{M^{* 2} Q}{\beta^{2}}+\frac{N Q}{\beta}-\frac{2 M^{*} p_{\zeta}{ }^{*}}{\beta}\right)_{0} \frac{\zeta^{3}}{3 !} \\
& +\left(-\frac{M^{* 3} N}{\beta^{3}}+\frac{3 M^{* 2} p_{\eta}{ }^{*}}{\beta^{2}}+\frac{M^{*} N^{2}}{\beta^{2}}-\frac{3 M^{*} Q^{2}}{\beta^{2}}-\frac{N p_{\eta}{ }^{*}}{\beta}-\frac{3 Q p_{p^{*}}}{\beta}\right)_{0} \frac{\zeta^{4}}{4 !} \\
& +\left(\frac{M^{* 4} Q}{\beta^{4}}-\frac{11 M^{* 2} N Q}{\beta^{3}}+\frac{4 M^{* 3} p_{5}{ }^{*}}{\beta^{3}}+\frac{N^{2} Q}{\beta^{2}}-\frac{3 Q^{3}}{\beta^{2}}-\frac{6 M^{*} N p_{5}{ }^{*}}{\beta^{2}}+\frac{16 M^{*} Q p_{\eta}{ }^{*}}{\beta^{2}}+\frac{4 p_{5}{ }^{*} p_{\eta}{ }^{*}}{\beta}\right)_{0} \frac{\zeta^{5}}{5 !} \\
& +\left(\frac{M^{* 5} N}{\beta^{5}}-\frac{5 M^{* 4} p_{\eta}{ }^{*}}{\beta^{4}}-\frac{11 M^{* 3} N^{2}}{\beta^{4}}+\frac{15 M^{* 3} Q^{2}}{\beta^{4}}+\frac{33 M^{* 2} N p_{\eta}{ }^{*}}{\beta^{3}}+\frac{45 M^{* 2} Q p_{\zeta}{ }^{*}}{\beta^{3}}+\frac{M^{*} N^{3}}{\beta^{3}}\right. \\
& \left.-\frac{33 M^{*} N Q^{2}}{\beta^{3}}+\frac{10 M^{*} p_{\zeta}{ }^{2}}{\beta^{2}}-\frac{20 M^{*} p_{\eta}{ }^{* 2}}{\beta^{2}}-\frac{N^{2} p_{\eta}{ }^{*}}{\beta^{2}}+\frac{25 Q^{*} p_{\eta}{ }^{*}}{\beta^{2}}-\frac{8 N Q p_{\zeta}{ }^{*}}{\beta^{2}}\right)_{0} \frac{\zeta^{6}}{6 !} \\
& +0\left(\zeta^{7}\right)
\end{aligned}
$$

$$
\begin{aligned}
& \left\{\begin{array}{l}
x_{G}(\zeta) \\
y_{G}(\zeta)
\end{array}\right\}=\left\{\begin{array}{l}
x_{G} \\
y_{G}
\end{array}\right\}_{0}+\left[T_{G}\right]_{0}^{T}\left(\left\{\begin{array}{c}
1+\frac{N}{\underline{\underline{\alpha}}} \\
0
\end{array}\right\}_{0} \zeta+\left\{\begin{array}{c}
0 \\
-\frac{M^{*}}{\beta}
\end{array}\right\}_{0} \frac{\zeta^{2}}{2}+\left\{\begin{array}{c}
-\frac{M^{* 2}}{\beta^{2}} \\
-\frac{Q}{\beta}
\end{array}\right\}_{0} \frac{\zeta^{3}}{3 !}\right.
\end{aligned}
$$

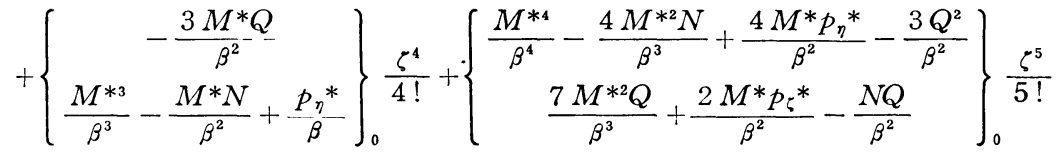

$$
\begin{aligned}
& \left.+\left\{\begin{array}{c}
\frac{15 M^{* 3} Q}{\beta^{4}}+\frac{10 M^{* 2} p_{5}{ }^{*}}{\beta^{3}}-\frac{15 M^{*} N Q}{\beta^{3}}+\frac{10 Q p_{\eta}{ }^{*}}{\beta^{2}} \\
-\frac{M^{* 5}}{\beta^{5}}+\frac{11 M^{* 3} N}{\beta^{4}}-\frac{13 M^{* 2} p_{\eta}{ }^{*}}{\beta^{3}}-\frac{M^{*} N^{2}}{\beta^{3}}+\frac{18 M^{*} Q^{2}}{\beta^{3}}+\frac{N p_{\eta}{ }^{*}}{\beta^{2}}+\frac{3 Q p_{5}{ }^{*}}{\beta^{2}}
\end{array}\right\} \frac{\zeta^{6}}{6 !}\right) \\
& +\left\{0\left(\zeta^{7}\right)\right\} \\
& \theta(\zeta)=\theta_{0}+\left(-\frac{M^{*}}{\beta}\right)_{0} \zeta+\left(-\frac{Q}{\beta}\right)_{0} \frac{\zeta^{2}}{2 !}+\left(-\frac{M^{*} N}{\beta^{2}}+\frac{p_{\eta}^{*}}{\beta}\right)_{0} \frac{\zeta^{3}}{3 !}+\left(\frac{M^{* 2} Q}{\beta^{3}}-\frac{N Q}{\beta^{2}}+\frac{2 M^{*} p_{\zeta}^{*}}{\beta^{2}}\right)_{0} \frac{\zeta^{4}}{4 !} \\
& +\left(\frac{M^{* 3} N}{\beta^{4}}-\frac{3 M^{* 2} p_{\eta}{ }^{*}}{\beta^{3}}-\frac{M^{*} N^{2}}{\beta^{3}}+\frac{3 M^{*} Q^{2}}{\beta^{3}}+\frac{N p_{\eta}{ }^{*}}{\beta^{2}}+\frac{3 Q p_{\zeta}{ }^{*}}{\beta^{2}}\right)_{0} \frac{\zeta^{5}}{5 !} \\
& +\left(-\frac{M^{* 4} Q}{\beta^{5}}+\frac{11 M^{* 2} N Q}{\beta^{4}}-\frac{4 M^{* 3} p_{\zeta}{ }^{*}}{\beta^{4}}+\frac{6 M^{*} N p_{\zeta}{ }^{*}}{\beta^{3}}-\frac{16 M^{*} Q p_{\eta}{ }^{*}}{\beta^{3}}-\frac{N^{2} Q}{\beta^{3}}+\frac{3 Q^{3}}{\beta^{3}}\right. \\
& \left.-\frac{4 p_{\zeta}^{*} p_{\eta}^{*}}{\beta^{2}}\right)_{0} \frac{\zeta^{6}}{6 !}+0\left(\zeta^{7}\right)
\end{aligned}
$$

ただし，前式中の $\left\{p_{r}^{*}, p_{\eta}^{*}\right\}$ は

$$
\left\{p_{5}^{*}, p_{\eta}^{*}\right\}=\left[T_{G}\right]\left\{\bar{p}_{x}, \bar{p}_{y}\right\}
$$

であり，下線＝を付した項は微小な重心線伸び率に対 する付加項を表わす.

式 $(23 \cdot a, b),(24 \cdot a, b)$ を始端状態量 $\boldsymbol{s}_{0}$ に関して微 分すれば, 式 (6) の形で 1 要素内の接線伝達マトリッ クス $\left[U\left(\zeta ; \boldsymbol{s}_{0}, \overline{\boldsymbol{p}}\right)\right]$ を得ることができる.

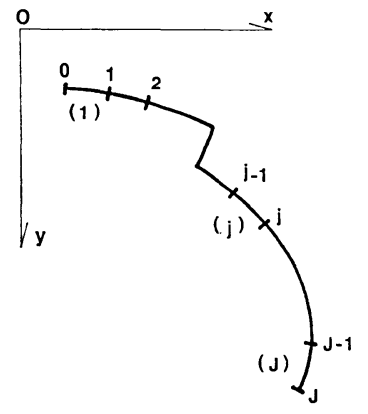

\section{（2）要素間伝達}

断面位置を $\boldsymbol{x}=\left\{x_{G}\right.$, $\left.y_{G}, \theta\right\}$ で規定するもの とすれば，(2)，2.で述 べた意味での対応する力 学量は, $\zeta$ の正の断面に 作用する $\{x, y\}$ 方向の 力成分 $\left\{F_{x}, F_{y}\right\}$ と回転 $\theta$ 方向のモーメント $M_{\theta}$

Fig. 2 Elemental Subdivision. の $\boldsymbol{f}=\left\{F_{x}, F_{y}, M_{\theta}\right\}$ で
あり, 状態量 $\boldsymbol{t}(\zeta)$ としては

$$
\boldsymbol{t}=\left\{x_{G}, y_{G}, \theta, F_{x}, F_{y}, M_{\theta}\right\}
$$

を考える.

1 ループ境界值問題のはりを $J$ 分割して節点番号と 要素番号を Fig. 2 のように定める. 代表要素（j）の 始端状態量 $\boldsymbol{t}_{j 0}$ に対して $\boldsymbol{s}_{j 0}=\left\{x_{G}, y_{G}, \theta, N, Q, M\right\}_{j 0}$ は, $\left\{F_{x}, F_{y}\right\}_{0}$ の $\{N, Q\}_{0}$ への変換と $M=-M_{\theta}$ の関 係より

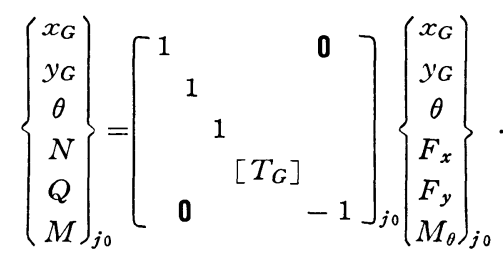

と表わされ， $\boldsymbol{s}_{j 0}$ に対する始端まわりでの式 $(23 \cdot \mathrm{a}, \mathrm{b})$ ， $(24 \cdot \mathrm{a}, \mathrm{b})$ の展開より $\zeta=\Delta l_{j}\left(\Delta l_{j}\right.$ : 要素長 $)$ までの伝達 関係

$$
\boldsymbol{s}_{j \Delta l}=\boldsymbol{E}_{j}\left(\Delta l ; \boldsymbol{s}_{0}, \overline{\boldsymbol{p}}\right)
$$


が定まり, $\boldsymbol{s}_{j \Delta l}$ に対する $\boldsymbol{t}_{j \Delta l}$ は, 式 (27) の逆の変換

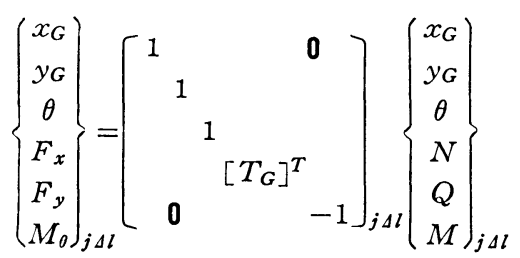

で表わされる. 式 (27), (28),(29) の関数関係を連続さ せて $\boldsymbol{t}_{j 0}$ に対する $\boldsymbol{t}_{\boldsymbol{j} \Delta l}$ を得ることができる.このとき， $\left\{F_{x}, F_{y}\right\}$ の伝達関係は, 静的つり合い条件より, 明ら かに

$$
\left\{F_{x}, F_{y}\right\}_{\Delta l}=\left\{F_{x}, F_{y}\right\}_{0}-\left\{\bar{p}_{x}, \bar{p}_{y}\right\} \Delta l
$$

$\left(\left\{\bar{p}_{x}, \bar{p}_{y}\right\}:\right.$ const.) であり, 前述の結果の $\left\{F_{x}, F_{y}\right\}$ の 行成分は式 (30) で修正することができる.

始端状態量 $\boldsymbol{t}_{j 0}$ の微小変化を考えて, 式 (27), (28), （29）の接線伝達を展開すれば, 式（27）に対して

$$
\left.\begin{array}{l}
\delta \boldsymbol{s}_{j 0}=\left[C_{j}\left(\boldsymbol{t}_{0}\right)\right] \delta \boldsymbol{t}_{j 0} \\
{\left[C_{j}\left(\boldsymbol{t}_{0}\right)\right]=\left[\begin{array}{cc}
1 & 0 \\
1 & 1 \\
& -\left[D_{G}\right]\left\{\begin{array}{l}
F_{x} \\
\left.F_{y}\right\}
\end{array}\right\},\left[T_{G}\right] \\
0 &
\end{array}\right]_{j 0}}
\end{array}\right\}
$$

$(31 \cdot \mathrm{a}, \mathrm{b})$

となり, 式 $(23 \cdot \mathrm{a}, \mathrm{b}),(24 \cdot \mathrm{a}, \mathrm{b})$ の展開式を $s_{0}$ に関し て微分すれば, 式 (28) の接線関係

$$
\delta \boldsymbol{s}_{j \Delta l}=\left[U_{j}\left(\Delta l ; \boldsymbol{s}_{0}, \overline{\boldsymbol{p}}\right)\right] \delta \boldsymbol{s}_{j_{0}}
$$

が得られ，式 (29) に対しては

$$
\left.\begin{array}{l}
\delta \boldsymbol{t}_{j \Delta l}=\left[C_{j}\left(\boldsymbol{s}_{\Delta l}\right)\right] \delta \boldsymbol{s}_{j \Delta l} \\
{\left[C_{j}{ }^{\prime}\left(\boldsymbol{s}_{\Delta l}\right)\right]=\left[\begin{array}{cc}
1 & 0 \\
1 & \\
1 & \\
-\left[D_{G}\right]^{T}\left\{\begin{array}{l}
N \\
Q
\end{array}\right\},\left[T_{G}\right]^{T} \\
0 & -1
\end{array}\right]_{j \Delta l}}
\end{array}\right\}
$$

と展開することができる．以上を用いて， $\boldsymbol{t}_{\boldsymbol{j}}$ に関する 1 要素内の接線伝達マトリックス $\delta t_{j \Delta l}=\left[U_{j}^{*}\right] \delta t_{j 0}$ は $\left[U_{j}^{*}\left(\Delta l ; \boldsymbol{t}_{0}, \overline{\boldsymbol{p}}\right)\right]$

$$
=\left[C_{j}{ }^{\prime}\left(\boldsymbol{s}_{\Delta l}\right)\right]\left[U_{j}\left(\Delta l ; \boldsymbol{s}_{0}, \overline{\boldsymbol{p}}\right)\left[C_{j}\left(\boldsymbol{t}_{0}\right)\right]\right.
$$

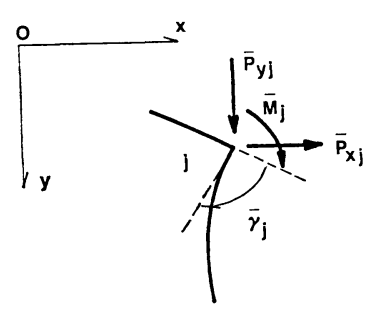

Fig. 3 Nodal Condition.
と表わされることにな る.ここで, $\left\{F_{x}, F_{y}\right\}$ の 伝達に関して前述と同様 に考えて, 式 (34) の対 応する行は $\delta\left\{F_{x}, F_{y}\right\}_{\Delta l}$ $=\delta\left\{F_{x}, F_{y}\right\}_{0}$ と修正す ることができる.

要素間の境界点 $j$ で,
集中外力 $\left\{\bar{P}_{x}, \bar{P}_{y}, \bar{M}_{\theta}\right\}_{j}$ が作用し角度 $\bar{\gamma}_{j}$ の折れ曲が りがある場合には（Fig. 3), 状態量 $\boldsymbol{t}_{\boldsymbol{j}}$ は

$$
\left\{\begin{array}{c}
x_{G} \\
y_{G} \\
\theta \\
F_{x} \\
F_{y} \\
M_{\theta}
\end{array}\right\}_{j+0}=\left\{\begin{array}{c}
x_{G} \\
y_{G} \\
\theta \\
F_{x} \\
F_{y} \\
M_{\theta}
\end{array}\right\}_{j-0}\left\{-\left\{\begin{array}{c}
0 \\
0 \\
\bar{\gamma} \\
\bar{P}_{x} \\
\bar{P}_{y} \\
\bar{M}_{\theta}
\end{array}\right\}\right.
$$

の階差連続となるが, 状態量変化に関する接線伝達は連 続 $\left(\delta \boldsymbol{t}_{\boldsymbol{j}+0}=\delta \boldsymbol{t}_{\boldsymbol{j}-0}\right)$ となる.

Fig. 2 のように $J$ 分割した全体区間 $l$ の伝達関係 は, 式 (27), (28), (29) の要素内伝達と式 (35) の節点 伝達を始端から終端の方向に連続させて得られ, 式 (34) の接線係数を連続させて, 全体の接線伝達マトリックス は

$$
\left[U^{*}\left(l ; \boldsymbol{s}_{0}, \overline{\boldsymbol{p}}, \overline{\boldsymbol{P}}_{j}\right)\right]=\left[U_{J}^{*}\right]\left[U_{J-1}{ }^{*}\right] \cdots\left[U_{1}^{*}\right]
$$

と表わされる。

\section{（3）数值解析}

[計算例 1] 級数展開 $(23 \cdot a, b),(24 \cdot a, b)$ の精度を みるために, Fig. 4 に示す片持はり $\left(A=0.6 \mathrm{~cm}^{2}, I=\right.$

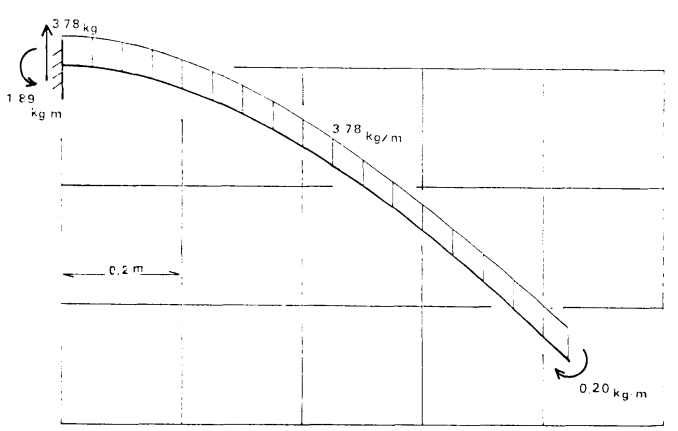

Fig. 4 Exact Equilibrium Configuration in Example $1(1 \mathrm{~kg}=9.8 \mathrm{~N})$.

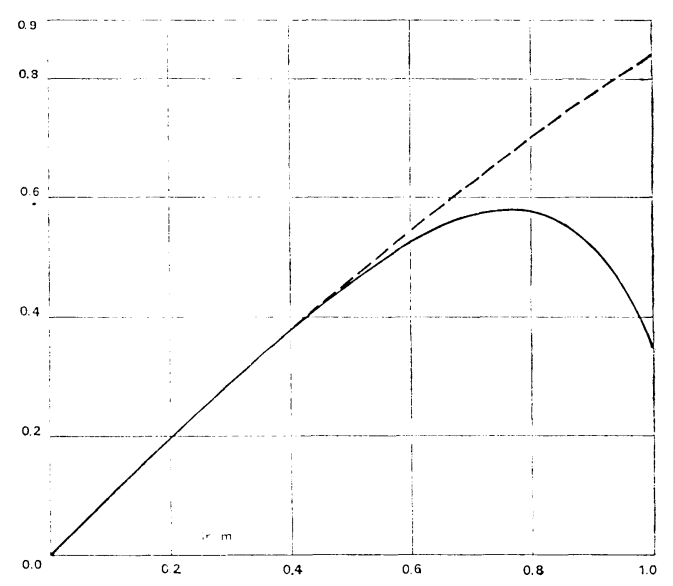

Fig. $5 x_{G}(\zeta)$ Distribution. 
$\left.0.45 \times 10^{-2} \mathrm{~cm}^{4}, l=1 \mathrm{~m}, E=0.21 \times 10^{7} \mathrm{~kg} / \mathrm{cm}^{2}\right)$ の初期值 問題を数值計算した. 線形理論での先端たわみ $2 l / 3$ 相 当の等分布荷 重 $p_{y}=3.78 \mathrm{~kg} / \mathrm{m}$, 支持反力 $F_{y_{0}}=3.78$ $\mathrm{kg}, M_{0}=1.89 \mathrm{~kg} \cdot \mathrm{m}$ を与えて, 数值的に 悠密と考えら れる 10 等分割 6 次展開の結果と全区間を 1 区間 6 次展 開したものを比較した. Fig. 4 は前述支持点反力に対

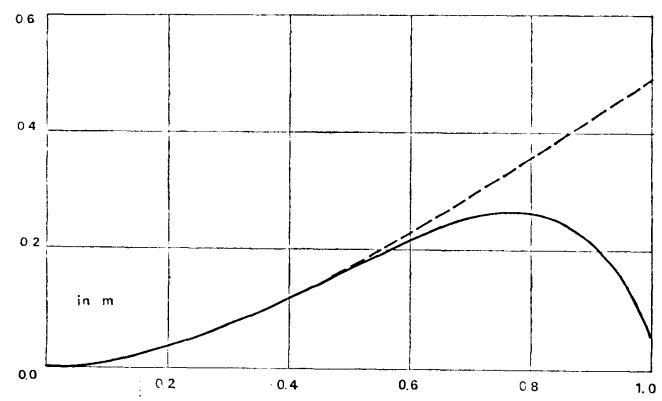

Fig. $6 y_{G}(\zeta)$ Distribution.

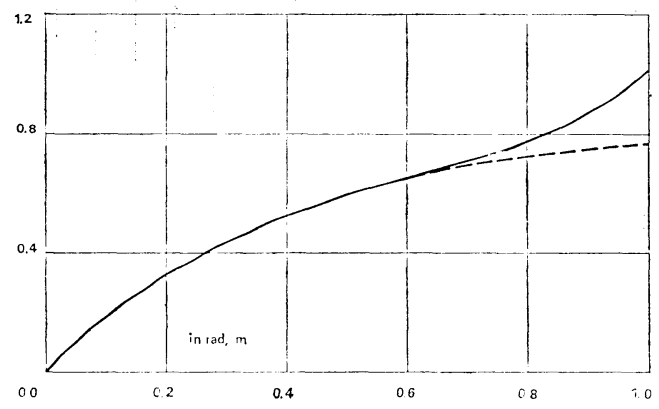

Fig. $7 \quad \theta(\zeta)$ Distribution.

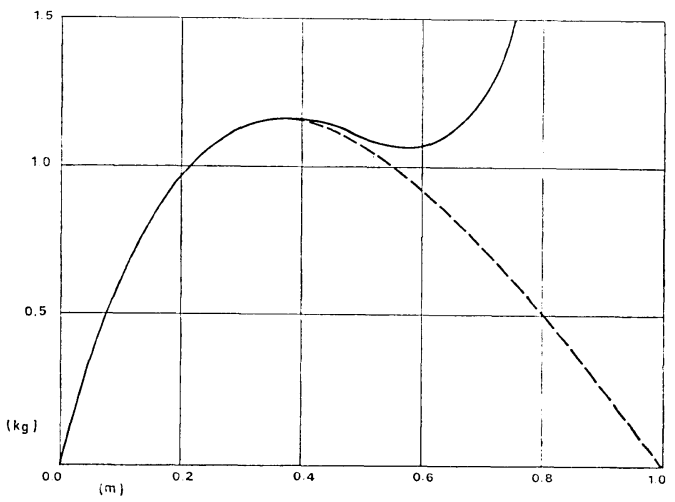

Fig. $8 N(\zeta)$ Distribution $(1 \mathrm{~kg}=9.8 \mathrm{~N})$.

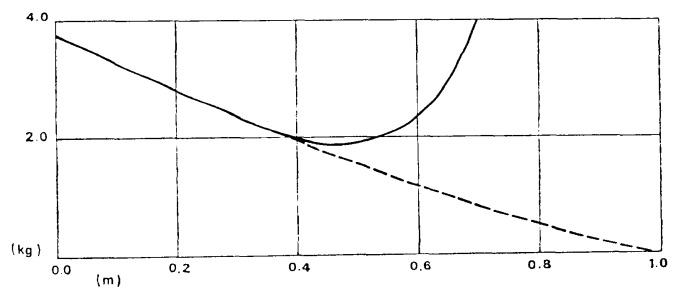

Fig. $9 Q(\zeta)$ Distribution $(1 \mathrm{~kg}=9.8 \mathrm{~N})$.

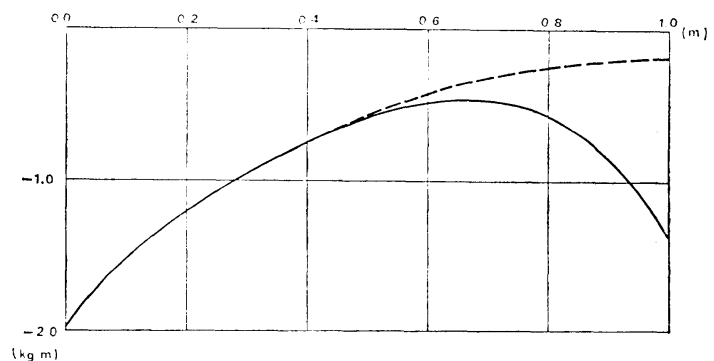

Fig. $10 M(\zeta)$ Distribution $(1 \mathrm{~kg}=9.8 \mathrm{~N})$.

して数值的に峳密と考えられるつり合い形状であり, Fig. 5, 6, 7, 8, 9, 10 は, それぞれ $x_{G}(\zeta), y_{G}(\zeta), \theta$ $(\zeta), N(\zeta), Q(\zeta), M(\zeta)$ の以上の比較であり, 破線は 10 分割展開, 実線が 1 区間展開を表わす，級数展開の 特徽として中央点付近までは十分な近似となっている が，それ以降では実線と破線は大きく離れる.

[計算例 2 ] 例 1 と同じはり（10 等分割, 6 次展開） を用いて単純支持の境界条件で数值計算を行った. 線形 理論での中央点たわみ $n l / 10, n=1,2, \cdots, 10$, に相当す る 鉛直等分布外力 $p_{y}=7.258 \sim 72.576 \mathrm{~kg} / \mathrm{m}$ を考えて,

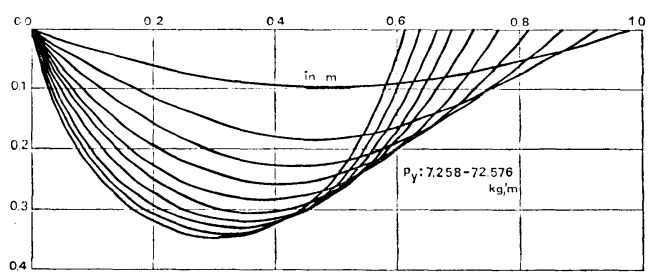

Fig. 11 Sequential Equilibrium Configurations for Uniformly Distributed Loads.

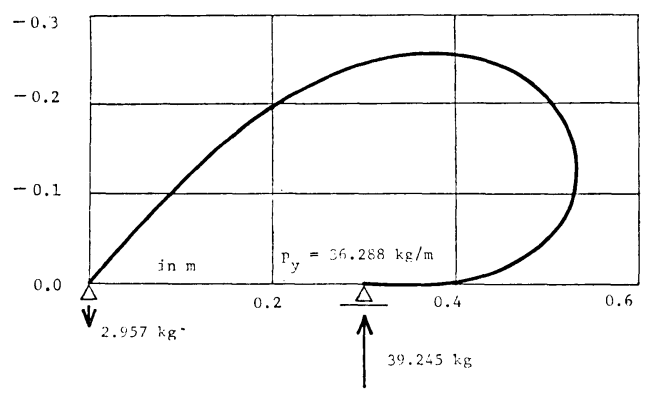

Fig. 12 Secondary Equilibrium Configuration for $P_{y}=36.288 \mathrm{~kg} / \mathrm{m}(1 \mathrm{~kg}=9.8 \mathrm{~N})$.

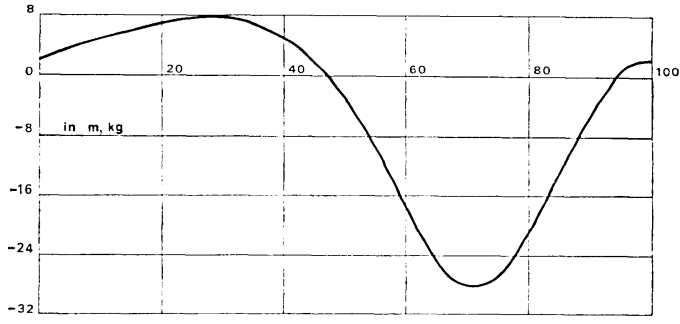

Fig. $13 N(\zeta)$ Distribution $(1 \mathrm{~kg}=9.8 \mathrm{~N})$. 


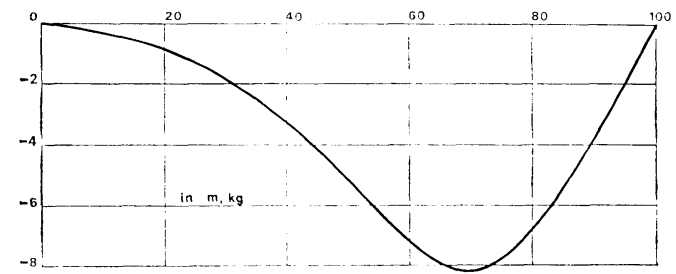

Fig. $14 M(\zeta)$ Distribution $(1 \mathrm{~kg}=9.8 \mathrm{~N})$.

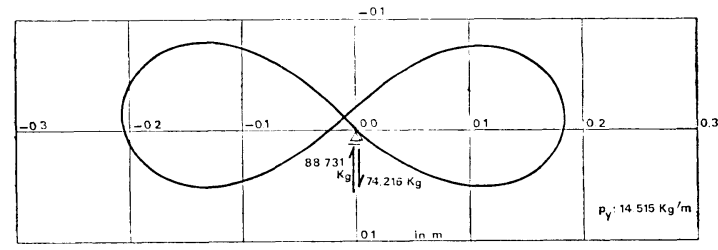

Fig. 15 Secondary Equilibrium Configuration for $P_{y}=14.515 \mathrm{~kg} / \mathrm{m}(1 \mathrm{~kg}=9.8 \mathrm{~N})$.

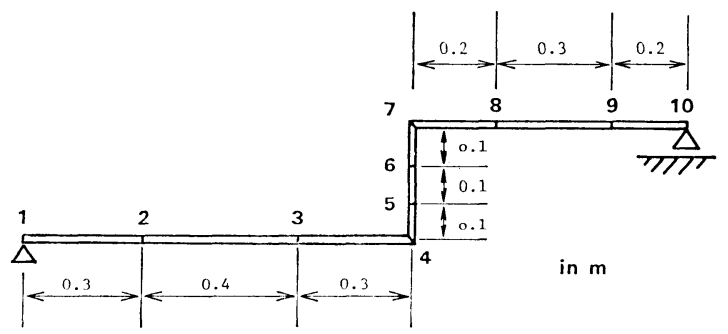

Fig. 16 Initial Configuration in Example 3.

各荷重の前段階荷重のつり合い状態での始端値を Newton-Raphson 法の初期值として与えて数值計算を継続し た.このときの連続したつり合い形状を Fig. 11 に示 す. Fig. 12 は， $l / 2$ たわみ相当の $p_{y}=36.288 \mathrm{~kg} / \mathrm{m}$ でのつり合い形状を N.R. 法での始端状態量の初期值を 零として直接数値計算したときの結果であり， Fig. 13, 14 はこのときの軸力 $(N)$ と曲げモーメント $(M)$ の 分布を示す. ここでは, 鉛直等分布外力に対するすべて のつり合い形状を組織的に調べることはしていないが，

Fig. 11 の線形外力経路に沿ったつり合い形状と異なる 場合として, 他には Fig. 15 のつり合い形状が, 線形 理論での $l / 5$ たわみ相当の $p_{y}=14.515 \mathrm{~kg} / \mathrm{m}$ に対して 同様に零值を N.R. 法の初期值としたとき計算された. なお, 以上の N.R. 法は, いずれも 10 回以内の繰返し で収束值を得ている.

[計算例 3] Fig. 16 に示す折れ曲がりはり $(A=0.9$ $\left.\mathrm{cm}^{2}, I=0.675 \times 10^{-2} \mathrm{~cm}^{4}, E=0.21 \times 10^{7} \mathrm{~kg} / \mathrm{cm}^{2}\right)$ で 節点

Table 1 Incremental Loads. 7 の鉛直方向集中荷重 $P_{\boldsymbol{y}}$ $\begin{array}{r}\text { Table } 1 \text { Incremental Loads. } \\ (1 \mathrm{~kg}=9.8 \mathrm{~N})\end{array}=80.360 \mathrm{~kg}$ に対するつり

\begin{tabular}{c|c|c}
\hline$P_{y}(\mathrm{~kg})$ & $v(\mathrm{~m})$ & $\begin{array}{c}\text { No. of } \\
\text { Iteration }\end{array}$ \\
\hline 32.144 & 0.4799 & 8 \\
56.252 & 0.5779 & 8 \\
80.360 & 0.6093 & 7 \\
\hline
\end{tabular}
合い形状を数値計算した.

Table 1 は, 3 段階の分割 載荷での $P_{y}$ 方向のたわみ と N.R. 法での収束回数を

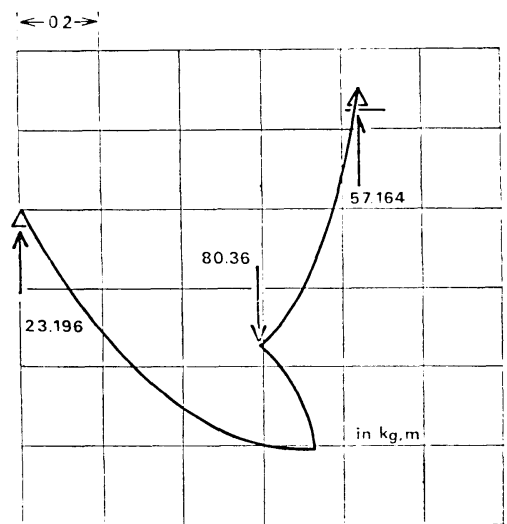

Fig. 17 Equilibrium Configuration for $P_{y}{ }^{7}=80.360 \mathrm{~kg}(1 \mathrm{~kg}=9.8 \mathrm{~N})$.

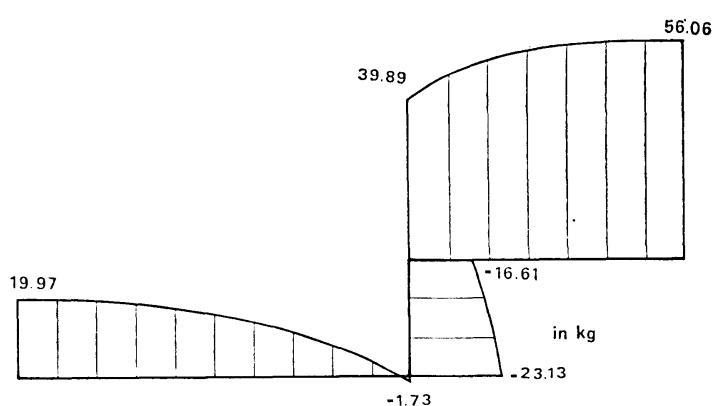

Fig. $18 N(\zeta)$ Distribution $(1 \mathrm{~kg}=9.8 \mathrm{~N})$.

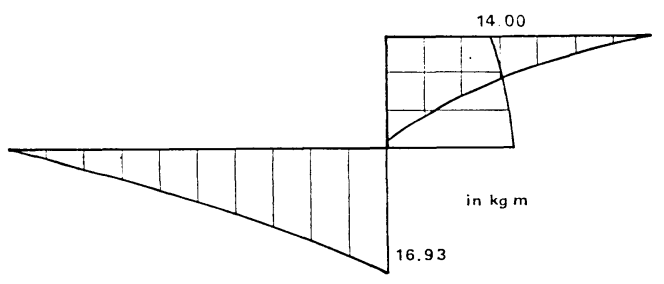

Fig. $19 M(\zeta)$ Distribution $(1 \mathrm{~kg}=9.8 \mathrm{~N})$.

表わす. $P_{y}=80.360 \mathrm{~kg}$ でのつり合い形状と軸力と曲げ モーメントの分布を，それぞれ Fig.17, 18, 19 に示す.

\section{4. 考察}

\section{（1）つり合い状態の多価性について}

本文で扱っている面内はりの有限変位問題では, 式 （7）の伝達関係は，その接線係数行列（式 (8)) の det. $\left[U^{*}\right]$ が正負江变化する程度の強非線形関係にあり，大 きい変位を生じさせる荷重を一度に載荷して目的とする つり合い形状を（たとえば Newton-Raphson 法等で） 求めることは一般にはできない，計算例 2 にみるように 最も簡単な構造の一つである単純はりであっても一つの 外力条件に対するつり合い形状はいくつかあり，外力経 
路や座屈点での分岐の方向等を規定しない限りつり合い 状態は 1 つに確定しない.

計算例 2,3 では, 線形の外力経路を規定する 意味で 簡単な段階載荷を考えて各段階で N.R. 法を適用してい るが，つり合い経路上で特異点がある場合では，それを N.R. 法等の手法で処理することはできない，両端境界 条件に対応させた式（9）の縮小された接線伝達マトリ ックス $\left[u^{*}\right]$ の境界条件満足のもとでの特異性は明らか につり合い状態のいわゆる座屈を意味するものであり, たとえば離散化変位法の系で種々に行われている数值計 算法と同様に, 特異点の処理をも含めて数値計算するこ とが考えられるが, 変位法離散系の安定・不定定理論 (たとえば Thomphson ${ }^{15)}$ ) 程度の 伝達関数法系での同 等の理論は示されていない.

\section{（2） 無限小要素分割の極限について}

本解法は 2. で述べたように連立 1 階 (非線形) 常微 分方程式のいわゆる Taylor 展開法であり, 1 区間の展 開幅 $\Delta l_{j}$ を無限小とする極限では 1 次展開で収束值が 得られることはよく知られている. 考察を厳密にするた めに有限ひずみ問題としての 1 次展開を以下に示すと

$$
\begin{aligned}
& \left\{\begin{array}{l}
N(\zeta) \\
Q(\zeta)
\end{array}\right\}=\left\{\begin{array}{l}
N \\
Q
\end{array}\right\}_{0}+\left\{\begin{array}{c}
-\frac{M^{*} Q}{\beta}-p_{\zeta}^{*} \\
\frac{M^{*} N}{\beta}-p_{\eta}^{*}
\end{array}\right\}_{0}^{\zeta+0\left(\zeta^{2}\right)} \\
& M(\zeta)=M_{0}+\left\{\left(1+\frac{N}{\alpha}\right) Q+\bar{m}\right\}_{0} \zeta+0\left(\zeta^{2}\right) \\
& \cdot(37 \cdot a, b) \\
& \begin{array}{l}
\left\{\begin{array}{l}
x_{G}(\zeta) \\
y_{G}(\zeta)
\end{array}\right\}=\left\{\begin{array}{l}
x_{G} \\
\left.y_{G}\right\}_{0}+\left[T_{G}\right]_{0}^{T}\left\{\begin{array}{c}
1+\frac{N}{\alpha} \\
0
\end{array}\right\}_{0} \zeta+\mathbf{O}\left(\zeta^{2}\right)
\end{array}\right\} \\
\theta(\zeta)=\theta_{0}+\left(-\frac{M *}{\beta}\right)_{0} \zeta+0\left(\zeta^{2}\right)
\end{array}
\end{aligned}
$$

となる. 重心線の不伸長の条件のもとに有限な曲げ変形 のみを考えた場合には，伸び剛性 $\alpha=\infty$ として下線 を付した項を消去した展開となり，また，いわゆる 有限変位微小ひずみ理論としての展開は以上 2 通りの中 間的立場にあると考えられる。

文献 8)にあるように，以上の展開結果を用いて，い わゆる要素の剛体変位除去のもとに幾何学的非線形問題 を離散化する手法の 必要最低展開次数を考察すること は, 興味深い. 要素座標の原点を要素の始端 $\left\{x_{G}, y_{G}\right\}_{0}$ におき $x$ 軸方向を始端軸線方向に定めた直交座標 $\{x$ ， $y\}$ に関する展開は, 式 $(37 \cdot \mathrm{a}, \mathrm{b}),(38 \cdot \mathrm{a}, \mathrm{b})$ で $\left\{x_{G}\right.$, $\left.y_{G}\right\}_{0}=\{0,0\},\left[T_{G}\right]_{0}=[I]$ とした展開に一致する.ここ で, 簡単のために, 有限な曲げ変形のみを考えて伸び変 形を無視 $(\alpha=\infty)$ して考えると, 前述の要素座標に関 する式 $(37 \cdot b),(38 \cdot a, b)$ は微小変位初等曲げ理論での
1 次展開と一致するが, 式 $(37 \cdot a)$ の 1 次微係数中 の $-(M * Q)_{0} / \beta,(M * N)_{0} / \beta$ は， $\zeta=0$ での状態量 $\boldsymbol{s}_{0}=$ $\left\{x_{G}, y_{G}, \theta, N, Q, M\right\}_{0}$ に関する 2 次非線形項であり， 当然ながらこれらは初等線形曲げ理論の展開式中には含 まれない.この軸力とせん断力に関する展開結果は, 文 献 8) での “ 1 次微係数までの範囲で線形理論に一致す る”という結論に低触する.このことは, さらに議論さ れるべき事柄と思われる.

一般のいわゆる有限要素展開では, 微小変位・有限変 位問題を問わず，その理論の範囲で構造要素の変形特性 は完備であるが, Taylor 展開法でのたとえば式 (37・a, b), $(38 \cdot \mathrm{a}, \mathrm{b})$ 程度の低次展開では, $\left\{x_{G}(\zeta), y_{G}(\zeta)\right\}$ が 軸力 $N_{0}$ による伸びた直線形状を示すのに対してたわみ 角 $\theta(\zeta)$ は $M_{0} *$ による曲率一定の純曲げ状態を表わし ており, さらにせん断力 $Q_{0}$ の変形への効果が含まれて いない等の（展開幅を十分小さくすることにより解消さ れる）矛盾点を含んでおり, 前述の意味での物理的な構 造要素と考えるよりも数值積分法上の要素 (分割区間) と考えた方が一般的概念にあてはまる.

\section{5. まと め}

本文は，伝達マトリックス法をはりの幾何学的強非線 形問題に拉大展開するにおいての基本的な定式化につい て述べているものであり, 解法上の特性は伝達マトリッ クス法のそれを受け継ぐ. ループ数の少ない 1 次元構造 要素の系を比較的小さいマトリックスで扱うことができ る反面, 有効に扱える構造の種類が限られるという実用 上の制約があるが, その力学問題の記述としての立場に 関して次のように考えることができる.

伝達関係を用いた手法とは, 基本的には常微分方程式 の系一般にあてはまる境界值問題の初期値問題への変換 という手法をはりの変形の問題に適用したものと考えて よいが，はりの変形の問題が系のひずみエネルギーと外 カポテンシャルで定まる変分問題であるということを展 開の表に明確には表現するものではない. 他の一つの主 流な手法である変位法では, 系の要素の変形力（応力） と変形（ひずみ）の間の構成方程式はその要素のひずみ エネルギーの変分といら立場で整理されるのが普通であ り, 節点変位 (変位) と要素変形（ひずみ）の間の適合 条件式は要素変形力 (応力) と節点力 (外力) の間のつ り合い関係と反傾関係にあり，このとき節点力と節点変 位の間にポテンシャルを考えることができるという変分 問題としての基本的な諸関係をそのまま解析手順の中に 組み込むことができる．これらの諸関係を規定すること は，一面で関数関係を制限することであるが，それらが 一般的に成立する意味では物理現象の一般論をより明確 
にしている.このように整理された変位法の系では，た とえば安定問題を考えるとき, その公理を解析手順の中 にきわめて合理的に含めることができるが，一方，伝達 マトリックス法, 伝達関数法等での展開式は, 前述の変 位法での現象の記述に比較して,これまでのところ十分 整備されて抢らず，その適用が基本的に制限されている ように思われる。

\section{参 考 文 献}

1) 阿井正博 ・西野文雄 : 離散化系の幾何学的非線形問題で の力学的関係と平面骨組への適用, 土木学会論文報告集, No. $304,1980-12$.

2）阿井正博・村上 淳: 面内曲げ有限変位問題での伝達関 数法について, 土木学会第 36 回年次学術講演会概要集, 第 I 部, 1981.

3) Austin, W.J. : In-Plane Bending and Buckling of Arches, J. of Str. Div., ASCE, Vol. 97, No. ST 5, pp. 1575 1592, May, 1971.

4) Becker, G. : Ein Beitrag zur Statischen Berechnung beliebig gelagerter ebener gekrümmter Stäbe mit einfach symmetrischen dünnwandigen offenen Profilen von in Stabachse veränderlichem Quershnitt unter Berücksichtigung der Wölbkrafttorsion, Der Stahlbau, H. 11 S. $334-346$ und H. 12 S. 368 377, 1965.

5）遠田良喜 : 伝達マトリックス法による 薄肉開断面曲線ば りの有限変位理論の解析, 土木学会論文報告集, 第 199 号, 1972-3.

6）遠田良喜：伝達マトリックス法, 構造工学講座.

7) 深沢泰晴・小林 潔: 薄肉曲線桁の 伝達行列とその変断 面連続曲線桁橋解析一の応用, 土木学会論文報告集, No.
244, 1975-12.

8）後藤芳顕・長谷川彰夫・西野文雄：平面骨組解析に打け る剛体変位除去の手法の精度, 土木学会第 37 回年次学術 䛾演会概要集, 第 I 部, 1982.

9) Harries, H. : Traglasten stählerner Zweigelenkbögen mit ausgebreiteten Fliesszonen, Der Stahlbau, H. 6 S.170 177 und H. 8 S. 248 252, 1970.

10) Möll, R. : Kippen von querbelasteten und gedrückten Durchlaufträgern mit I-Querschnitt als Stablitätsproblem und als Spannungsproblem III. Ordnung behandelt, Der Stahlbau,H. 3 S. $69-77$ und H. 6 S. $184 \sim$ 190, 1967.

11）波田凱夫・新家 徹・頭井 洋 : 伝達マトリックス法に よるアーチの面内弾性座屈 および 2 次応力問題つ解析, 土木学会論文報告集, 第 224 号, 1974-4.

12) Unger, B. : Elastisches Kippen von beliebig gelagerten und aufgehängten Durchlaufträgern mit einfachsymmetrischem, in Trägerachse veränderlichem Querschnitt unter Verwendung einer Abwandlung des Reduktionsverfahrens als Lösungsmethode, Der Stahlbau H. 5 S. 135 142, und H. 6 S. 181 185, 1970.

13）山森広一・吉田 博: 伝達マトリックス法による門形ラ 一メンの面外座屈解析, 土木学会論文報告集, No. 275 , 1978-7.

14) Yoshida, H. and Y. Imoto : Inelastic Lateral Buckling of Restrained Beams, J. of Engr. Mech. Div., ASCE, Vol. 99, No. EM 2, pp. 343 366, Apr., 1973.

15) Thomphson, J.M.T. : A General Theory for the Equilibrium and Stability of Discrete Conservative Systems, ZAMP, Vol. 20, 1969.

(1983.3.18 • 受付) 